\title{
A TERÜLETI ÉRDEKKÉPVISELET, A TERÜLETI POLITIKA ÉS A NORMATÍV SZABÁLYOZÁS ALAPKÉRDÉSEI
}

\author{
(Fundamental issues of the representation of regional interests, \\ of regional policy and normative regulations)
}

\section{CSEFKÓ FERENC}

\section{Területi érdekartikuláció}

A területi politika , fổ csapásainak" meghatározása olyan jelentôségû kérdés, melynek alaptételeiben társadalmi konszenzusra kellene jutni, azon alapulva, hogy a rövidebb-hosszabb távon megvalósuló területi fejlổdés független kell legyen pl. a ,,mindennapi parlamenti” döntések mechanizmusától. Sokakkal egyezôen én is azon az állásponton vagyok, hogy a korábbi területfejlesztési (sorvasztási) politika szétesett, de - és sajnos - helyébe eddig nem lépett egy új, a jogállamiság és a piacgazdaság követelményeinek eleget tevố területi politika. Ehelyett a pártérdekek mentén (jórészt a kormánykoalíció érdekei szerint) születnek egy-egy térség problémáinak (látszat) megoldására döntések.

Van a kérdésnek egy másik vetülete is. Ez pedig, hogy a parlamenten belüli ,,pártokon felül, kívül álló" (avagy éppen azokat keresztező) érdekek, ,területi-térségi lobbyk” milyen erốvel (eredményességgel) tudnak föllépni meghatározott területi célok érdekében, szövetkezve egy ügy sikeréért.

Érdekes kẻrdés az is, hogy mikor alakulnak, szervezôdnek (akẩr eseti jelleggel is) térségi lobbyk, s hogy ezek eredménye hol, mikor jelenik meg a központi hatalom döntéseiben. Tehát, hoz-e határozatot a Parlament kisebb-nagyobb tảj, térség fejlesztésének szüksẻgességérôl (mint ahogy ezt megtette az Alföld estében), más térségek , ,rovására" történô preferálásáról, és végül hogy áttekinti-e - ebból a szempontból - hazánk régióit (avagy magát a területbeosztást), s \$zületnek-e mindegyikre normatív döntések?'

A területi, regionális politika elveinek, irányainak kidolgozásakor biztosítandó, hogy az igen bonyolult, egymásnak is ellentmondó, egymással konkuráló érdekek felszínre kerüljenek, hogy az érdekvédelem, -képviselet és a , hatalom” szervezetei partneri viszonyba kerülhessenek egymással. Ehhez megfelelố garanciarendszer kiépítése, a hatáskörök és feladatkörök pontos rögzítése szükséges. ${ }^{2}$

A Kormány , ,csupán” alkotmányos kötelességeit teljesíti, amikor döntési tervezeteit egyezteti a különbözó (érdekelt) társadalmi szervezetekkel. Ha ezt nem tenné - egyszerủen fogalmazva --, alkotmánysértést követne el. Az egyeztetések alanyi oldalának tisztázása, mármint az, hogy ki a , másik oldal”, azonban nem is olyan egyszerú, mivel a , társadalmi szervezet” fogalom alá vonható szervezôdések sokszínû, típusú, hatáskörũ, érdekeltségű, koordinációjú stb. rendszert alkotnak. 
Másrészt gond annak meghatározása, hogy mitől válik egy társadalmi szervezet ,érdekeltté”, azaz , ki” dönti el, hogy valamely szervezódés egy adott stratégia vagy akár konkrét ügy kapcsán e körbe tartozik-e vagy sem, s mi történik akkor, ha kimarad e szervek közül, mivel csak (és esetleg) közvetetten érintett az ügyben? S ehhez képest vizsgálandó, hogy a Kormány és annak szervei kit és mikor vonnak be egy-egy döntés elôkészítésébe. ${ }^{3}$

Mindezen lehetne változtatni azzal, ha - pontosan a regionális politikával összefüggésben kiépülhetne egy hatékony, ,,markáns”, rugalmas és konzisztens területi érdekvédelmi, érdekképviseleti rendszer - szolgálva ezzel az ország különbözổ térségeit, tájegységeit. Olyan rendszer, amely képes reagálni ,,a gyorsan változó" világra, amely bizonyos összhang megteremtésére is alkalmas a helyi (térségi) válságkezelés és a kormányzati programok között.

Az érdekartikuláció kapcsán arra is figyelemmel kell lenni, hogy bizonyos térségek között tartós (vagy esetenkénti) érdekazonosságok, míg mások között jelentôs érdekkülönbségek mutathatók ki. Nem zárható tehát ki a régiók, kisebb-nagyobb területek, tájegységek egymás elleni föllépése sem. ${ }^{4}$

Az érdekközvetítô szervezetek kapcsolati rendszere szempontjából alapvetổ kérdés, hogy kormányzati szinten miként alakul a területpolitikai döntések elôkészítésének, végrehajtásának szervezetrendszere. Napjainkban sem zárult még le a vita a Belügyminisztérium és a Környezetvédelmi és Területfejlesztési Minisztérium között a település- és területfejlesztés szervezeti, hatásköri kérdéseiben. Sổt, úgy látszik, mintha alapvetố konceptuális különbségek lennének pl. a területi szint, vagy éppen az intézményrendszer (dekoncentrált szervek, KMB-hivatalok), avagy egyáltalán a törvényi szabályozás tárgya, tartalma, szükségessége vonatkozásában.

Elengedhetetlen tehát ,,állami vonalon" a döntési szintek (és eljárások) konzisztens rendszerének kimunkálása, mert csak ebben az esetben múködhetnek hatásosan az érdekközvetító, -képviselố mechanizmusok. ${ }^{5}$

Az önkormányzati rendszeren kívül mára létrejött (s tovább burjánzik) a legkülönbözóbb típusú, funkciójú, szervezettségư ,,dekók” rendszere. Ezek túlnyomó részének tevékenysége egymástól is izolálódott. Ugyanakkor nem létezik átfogó területi információs rendszer, amely nélkül viszont egyszerüen nem lehet következetes, tervszerü (de legalábbis hosszabb távra elôrelátó) területi politikát folytatni. Újabb problémát jelent, hogy az érdekképviseleti szerveknek az ezekhez való kapcsolatrendszere szinte teljesen kimunkálatlan, esetleges, vagy semmilyen.

A, ,társadalmi oldalról" számba vehetố érdekszervezetek között helyi, megyei, térségi, táji, regionális és országos, egymásra épülố és egymástól függetlenül múködổ egyaránt megtalálhatók (s ezek szövetségei is).

A pártok törvényhozást illetổ szerepe elvileg viszonylag tiszta képet mutat. Korántsem egyértelmú azonban megyei (helyi) szervezeteik kapcsolatrendszere egyrészt saját pártjukon belül, másrészt a megye (térség) állami-politikai döntéshozatali mechanizmusában. A Parlamenten kívüli pártokról, helyi pártokról, pártszerû́ képződményekrôl csak annyit, hogy ,,ôk is vannak”, érdemi beleszólási lehetôségük azonban nincs az országos regionális politika alakításábaalakulásába.

Az intézményes kereteken túli területi érdekartikulációs lehetôségek kidolgozatlanok. A társadalmi viták intézményét az új Parlament (elsô intézkedései között) eltörölte. Az országos népszavazás (értelemszerü adaptálással a , ,helyi szavazás”) csak érintőlegesen kapcsolható ide. ${ }^{\circ}$ 
A civil társadalom, elvileg, egyéb keretek között is aktív szerepet vállalhat térségi érdekei megjelenítésében: pl. különbözô akciók, petíciók, tiltakozások, felvonulások, demonstrációk, a bojkott, a sztrájk, a ,,népi (polgári) engedetlenségi mozgalmak”, meghatározott célra szervezổdött, régiókon is túlnyúló megmozdulások.

Az elốzổekben jelzett szervezeteknek, intézményeknek, mozgalmaknak stb. érdekképviseleti tevékenységeiket illetốen is tisztázandó a kapcsolatuk ,,az illetékes" döntéshozó szervekkel, \$az önkormányzatokkal. Másrészt pedig mû́ködésük, ,társadalmi", önkéntes jellege, esetlegessége és eshetốlegessége is figyelembe veendõ. Megjegyzendố azonban, hogy a jogi szabályozás ilyen szempontból alig foglalkozik velük, s nagyrészt az adott állami, önkormányzati szerveken múlik, hogy bevonják-e ốket a döntések elókészítésébe, hogy figyelembe veszik-e azt a társađalmi-polgári (települési-térségi) erốt, amit (akiket) képviselnek.

\section{A területi érdekképviselet önkormányzati lehetóségei}

A társadalmi jellegư (és ehhez ,,rendelt" autonómiával, önkormányzattal rendelkezó) szervezeteket követổen érdemes röviden áttekinteni, hogy az alapfunkciójukat illetôen is a polgárok megbízásából (érdekeik védelmében) eljárni köteles és hivatott önkormányzatoknak milyen lehetôsségük nyilik ,,beleszólni” a területi politika alakulásába, a területfejlesztési döntésekbe. A probléma fốként a települési önkormányzatok esetében izgalmas, hiszen ezek a területfejlesztés, kistérségfejlesztés és a településfejlesztés ütközőpontjai, no meg serkentők is egyben.

Az eszközök között a ,,véleménynyilvánítás", , ,kezdeményezés” joga (az ún. felterjesztési jpg) - e kérdések tekintetében is - minden helyi önkormányzatot megillet. Igaz ugyan, hogy ez nem erôs jogosítvány, hiszen nincs jogkövetkezménye, annyit azonban a törvény is előir, hogy az illetékes szerveknek érdemben válaszolni kell fölvetéseikre.

$\mathrm{Az}$ önkormányzatokat érintố bármely ügyben az adott kérdésben hatáskörrel rendelkezố szervhez lehet fordulni. Az önkormányzatok az adott szerv által irányított szervek múköódésével, illetốleg az általa kibocsátott jogszabályokkal, a jogi irányítás eszközeivel és egyéb döntéseivel kapcsolatban is véleményt nyilváníthatnak, kifogással élhetnek, s kezdeményezhetik annak nhegvảltoztatását, visszavonását.

A minden nökormányzatot megilletố jogosultságon túl, pontosan a területi érdekmechanizmusokra tekintettel, külön is érdemes foglalkozni a területi szint (egység) sajátos helyével, szerepével a regionális politika alakításában.

Talán megfogalmazható az, hogy akár lesz területfejlesztési (településfejlesztési) törvény, akár nem, s bármilyen eszköz- és intézményrendszereket is építenek ki, ,,az élet” rövidebbhosszabb idốn belül valószínú kikényszerít valamilyen középszintet, már csak azért is, mert ą esélyegyenlốtlenségek, egyes térségek lemaradása nô, amelyeket így-úgy, de mérsékelni, befolyásolni kell. Másrészt vannak olyan funckiók, és mindig is lesznek, amelyek nem láthatóak el a települések közigazgatási határain belül, hiszen hozadékai vagy éppen káros hatásai jôvval túlmutatnak azon, tehát igénylik a települések közötti térségi koordinációt, míg a központi hatalom szervei erre közvetlenül nem képesek, ennek a célnak nem felelhetnek meg.

Az önkormányzati törvényben a , ,területfejlesztés" (az ehhez kapcsolódó jogosítványokkal) nem szerepel. A belügyminiszter feladatainak meghatározásakor ugyanakkor azt írja a törvény, 
hogy ổ (ti. a belügyminiszter) ,,összehangolja a megyei önkormányzatok múködésével összefüggổ fejlesztés, tervezés és gazdálkodás feladatait." Ebból tehát az következik, hogy ilyen funkciói vannak a megyének. (?)

A másik, némiképp ,,rejtett" jogosítványa (?) a megyének az érdekvédelem. Igaz ugyan, hogy az önkormányzati törvényben magában nem, csupán az indoklásában találunk utalást a települések érdekképviseletére. Megjegyzem - erre még visszatérek -, hogy az önkormányzatokat saját jogon megilletố érdekképviselet mellett a törvény ezt a jogot általános jelleggel az országos önkormányzati szövetségekre ruházta. ${ }^{7}$

A harmadik, talán eddig nem elegendô hangsúlyt kapott normaszöveg, amely szerint a helyi önkormányzás joga a választópolgárok közösségét illeti meg, tehát a törvényalkotó ilyen ,,közösségnek" tekintette magát a megyét is. Ha pedig ez így igaz, akkor kell, hogy megjelenjen a megyei (területi) érdek is.

A települési önkormányzatokkal mellérendeltségi, partneri viszonyban lévổ megyei önkormányzatoknak a törvény szerint a közös érdekeltség alapján kell eljárniuk. Azonban elôfordulhatnak jelentôs érdeksérelmek, érdekellentétek is, amelyek megoldási módozatai ma még kidolgozatlanok.

Az önkormányzati törvény értelmében a megye szabadon vállalhat olyan közfeladatokat, amelyek gyakorlása nem sérti a megye által képviselt községek és városok érdekeit. Ha figyelembe vesszük, hogy területfejlesztési hatáskörök nincsenek más szervnél, akkor a megye elvileg - közfeladatnak minősítvén - eljárhat ezekben az ügyekben.

A hatásköri törvény külön címben foglalkozik a környezetvédelmi és területfejlesztési igazgatással. Ezen belül míg a rendezési tervek elfogadása - különbözỏ egyeztetési eljárások mellett - a települési önkormányzat hatáskörébe tartozik, addig a területfejlesztéssel és településrendezéssel, továbbá a környezet épített és természetes elemei védelmének összehangolásával kapcsolatos feladatokat, ha azok a megye egész területére vagy egy részére terjednek ki, a megyei önkormányzat látja el.

A területi szintũ érdekkifejeződés ,,csatornái” szempontjából lényeges kérdés a települési önkormányzatokkal való kapcsolat, az információ-áramoltatásban való közremüködés, szakmai segítségnyújtás, esetenkénti közremúködés egy-egy olyan konkrét területfejlesztési, települési probléma (pl. környezetvédelem, vízgazdálkodás) megoldásában, amely túlmutat az adott önkormányzat közigazgatási határain, s térséginek minôsíthető.

A területfejlesztési tevékenység egyik legfontosabb vonalát képezik a vállalkozói, menedzselési feladatok. Ez nem csupán koordinációs tevékenységet jelent, hanem azt is, hogy maga az önkormányzat is a piac részesévé válik, tulajdonával, javaival vállalkozik, üzleti tevékenységet folytat. Végsôsoron azonban itt sem a saját maga, hanem a megye településeinek, térségeinek a fejlôdése-fejlesztése érdekében.

A civil szerveződések, egyesületek vonatkozásában a kapcsolatok elsổsorban a folyamatos információáramoltatást, egymás tevékenységének megismerését, esetleges konfliktusok megoldását, a lakossági kapcsolatok erôsítését, adott ügyekben közös fellépést, $\mathrm{s}$ - bár ez manapság kétséges (!) - az országos politika formálásában való részvételt jelenthetnek.

Alulról építkezố, az adott térségek sajátosságaira, elképzeléseire támaszkodó területfejlesztési koncepciók, tervek készítésére lenne szükség. E ,,sokszereplôs" folyamatban olyan érdekegyeztetésen alapuló mechanizmusok kiépítése indokolt, ahol valamennyi érdekcsoport megta- 
lâlja helyét, lehetốsége van álláspontja kifejtésére, annak a döntésekben való tükröztetésére. Ebbe a folyamatba be kell vonni minden olyan szervezetet, amely érdekelt lehet a területi fejlốdésben.

\section{A társulások, településszövetségek területfejlesztési, érdekképviseleti lehetốségei}

Az önkormányzati törvény többfajta társulási lehetốséget biztosít az önkormányzatok számára. Tény azonban, hogy az elmúlt egy-másfél esztendóben a települések nem igazán éltek ennek a lehetốségeivel, remélhetố hasznával. Ehelyett inkább a megyék voltak azok, amelyek jó néhány helyen kezdeményezôen léptek föl.

A társulások között sajátos helyet foglalnak el azok, amelyek szinte az egész megyét átfogják, s amelyeket egy adott megyei önkormányzat és a települési önkormányzatok kisebb-nagyobb számban kötöttek, többek között , ,... a területi feladatok hatékonyabb, célszerúbb megoldása", „.... a vállalkozások menedzselése, a körzeti jellegû̉ közszolgáltatások szervezése érdekében”" E társulási forma kiteljesedése, fổként, ha tervezési, fejlesztési feladatokat is ellátnak, egy meghatározott ellátási-szolgáltatási kvázi (majdnem) középszintnek felel meg, s egyben konkrét területfejlesztési döntésekben realizálódik. A társulás feladatainak meghatározó része tehát a település- és területfejlesztés terén jelentkezik. ${ }^{8}$

A településszövetségek, a kistérségi szervezôdések sokoldalúan kapcsolódhatnak be a területi politika alakításába. A törvényhozással kapcsolatban gyakorolhatják az ốket illetố jogokat, de részt vehetnek az érdekegyeztetố mechanizmusok kidolgozásában, nagyberuházások, fejlesztések, térségi programok kialakításában (ezek véleményezésében). Ugyancsak feladataik kỏzött szerepelhet a szolgáltatások szervezése, információáramoltatás kialakítása, érdekkonfliktusok feloldása, pályázatok, alapítványok kiírása, nemzetközi-regionális kapcsolatok kiépítésének segítése. Közremúködhetnek kisebb-nagyobb térségek életét befolyásoló regionáli|s léptékû̉ nemzetgazdasági feladatok kimunkálásában, a regionális kủlönbségek, az esélyegyenlốtlenségek csökkentésében, ezzel is bővítve a jelenlegi területfejlesztési kormányzati eszköztárat.

Az országban mind markánsabban jelennek meg a megyén belüli kistérségi érdekek. Az ezeket összefogó szövetkezések létrejöttek, mûködnek, bár egymáshoz képest is eltérố szervezettséggel, hatáskörrel és feladatkörrel.

E szövetségek célkitűzései között olyanok szerepelnek, amelyeket általában is meghatároznak maguk számára az országos települési érdekszövetségek; e szövetségek továbbá érdekközvetítố és érdekvédố tevékenységet is folytatnak az érintett önkormányzatok képviseletében regionális és országos szinten.

Azért foglalkoztam a kistérségi szövetségekkel, mivel vállalt feladataik közül nem egy megtaląlható a megyénél írtaknál, s az országos szövetségeknél is. A kérdés azonban, hogy ezek hogyan kapcsolódjanak egyrészról az országos szervezetek rendszerébe, másrészt ki az ố,,partnerik" a területi-térségi döntési mechanizmusban.

A közeljövổ egyik legfontosabb feladata a különbözố szövetségek közötti hatékony együttmûködés megteremtése. Szükség van rugalmas együttmũködésre, koordinációra, egymás közötti 
belsổ információ-áramoltatásra, a vélemények ismertetésére és ütköztetésére, egyes esetekben egymás befolyásolására, bizonyos kérdésekben közös fellépésre.

Amennyiben megvalósulna az önkormányzati érdekszövetségek integrációja, akkor állástfoglalhatnának olyan kérdésekben, mint pl., hogy milyen anomáliák mutatkoznak a központi és a helyi hatalom, az állami és önkormányzati rendszer, a centralizáció-decentralizáció, a hatás- és feladatkör-telepítés stb. kérdéseiben, s milyen irányú változtatások lehetnek indokoltak; az önkormányzati jogok garanciális védelmének helyzete, továbbfejlesztése, biztosítékai, hatékony érdekvédelmi, érdekképviseleti rendszer feltételei, horizontális és vertikális információs rendszer; a területi fejlôdéssel, terület- és településfejlesztéssel kapcsolatos kérdések stb.

Összefoglalva az elózôeket egy mondatban: egyrészt a területi érdekképviselet jövôje függ az elôzoóekben írtaktól, másrészt azonban attól is, hogy miként alakul a Magyar Köztársaság politikai-állami döntéshozatali, képviseleti, területbeosztási rendszere, azaz a majdan megvalósítandó jogállam és szociális (!) piacgazdaság milyen alkotmányos kereteket követel, illetve milyen alkotmányos keretek épülnek ki.

\section{A területi politika jogi szabályozásának néhány kérdése}

A területi politika terrénuma olyan ,,sarkalatos" törvényhozási tárgy, amely vetekszik sok egyéb, ugyancsak jelentôs parlamenti jogszabállyal, mégpedig átfogó jellege, komplexitása, más törvényekhez való kapcsolódása, a társadalom, illetve a különbözô térségek érdekrendszerét különbözố módon érintố volta miatt. ,SSúlya” jóval túlmutat egy ,,egyszerû́” törvényen fogalmazható meg az egyik fajta álláspont.

A másik szerint viszont nemhogy ily jelentổséggel nem bír, de egyáltalán nincs szükség törvényi normára, mivel nem lehet szabályozni - fốként a piacgazdaság körülményei között. Ellenkezne több más jogszabállyal, túl bonyolult lenne, keretjellegủ normának nincs értelme, részletezổt pedig nem lehet alkotni, mert az sértené pl. az önkormányzati jogokat stb. - füzhetôek tovább az ellenérvek.

A magam részérôl - az elsổ nézetet vallókhoz tartozva - szükségét látom a normatív szabályozásnak, ezért a továbbiakban erre vonatkozóan fejtem ki nézeteimet. ${ }^{9}$

A polgári demokráciák tapasztalatai is igazolják, hogy az állam nem maradhat ki a térségi, területi folyamatok alakításából, vagyis magából a területfejlesztésból, hanem abban különbözô - közvetlen és közvetett -, idôszakonként is változó eszközökkel kell szerepet vállalnia. ${ }^{10}$

Az elvégzendô feladatok közül a terület- és településfejlesztési politika kidolgozása után annak törvényi rögzítése kívánkozik az élre, vagyis hogy melyek azok az alapelvek és fó célok, amelyek rövid- és hosszú távon meghatározzák a fejlesztési tevékenységek irányát, valamint melyek a megvalósítás elemi biztosítékai.

A szabályozás célja lehet, hogy jogi erổre emelje a területpolitika alkalmazását jelentố területfejlesztés eszköz- és intézményrendszerét, alkalmazásának kormányzati munkamegosztását, területi szintû koordinációs mechanizmusait.

A célkitũzések állami normába öntése persze várhatóan igen sok akadályba ütközik majd. Fakad ez egyrészt az elvek jogi kérdéssé történổ megfogalmazásának gondjaiból, a részletezố szabályok kidolgozása során felmerülố problémákból, a különbözố szervezetek - köztük ki- 
emelve az önkormányzatokat, érdekszövetségeket és a , fốhatóságokat” - egyeztetési eljárásainak zökkenőiből, az eszközök kiszélesítésének bizonytalanságaiból stb.

A jogi szabályozás elókészítése két, egymáshoz szorosan kapcsolódó feladatot jelent. Egyré\$zt a hatályos joganyag átalakítását, , , karbantartását”, másrészt új jogi normák megalkotását.

Fölvethetố az alapvetổ szabályok alkotmányba történổ iktatása is. Ilyen lehet a települések és területi egységek meghatározása, az önkormányzatiság témánkhoz kapcsolódó elemi garanciăi, az alapvetổ területi és települési érdekek alkotmányos szinten történổ megjelenítése, a központi kormányzásnak a területek és települések iránti ,, kötelmei" stb. ${ }^{11}$

A lehetségesnek tûnố megoldásokat szerintem két végpont között lehet keresni: készüljön átfogó, kódexjellegú törvényi szintũ szabályozás; avagy a terület- és településfejlesztés kérdéseit az egyes ágazatok körében rendezzék.

Úgy és olyan törvényt kell alkotni, amely szervesen illeszkedik a szabályozni kívánt területhez kapcsolódó más törvényekhez, s nélkülözi egyben az ágazatok közötti presztízsharcokat; illetve az állam minimális mérvủ egyensúlyozó szerepvállalása, beavatkozási lehetổségének és eszközeinek rögzítése mellett garanciákat ad az önkormányzati jogok védelmére. Azaz, olyan eljárási, érdekegyeztetési megoldások kidolgozása szükséges, amely biztosítja a - részben szuverén döntési mechanizmusok mưködését, azon elvet is figyelembe véve, hogy végsố soron a terület- és településfejlesztésben a kormányzat és az önkormányzatok egyaránt érdekeltek.

A törvényhozás során legfontosabb ,,igazodási vonal" az önkormányzati törvénnyel összefüggésben húzható meg, nem elfelejtve azon garanciális szabályt, hogy kötelezô feladat elöírása esetén az országgyủlésnek gondoskodnia kell a feladat ellátásának pénzügyi fedezetéról és a szükséges eszközökrôl.

A területfejlesztési törvény elôkészítésekor annak idején foglalkozni kell majd a hatás- és feladatkörökkel is, értelemszerúen kitérve arra, hogy mely szintnek, illetve milyen szervezetnek milyen feladatokat és hatásköröket szab meg a törvény.

A Kormánynak egyébként az alkotmányos jogértelmezésból fakadóan nem kötelessége a Parlament elé vinni (e kérdés vonatkozásában) az Alkotmány végrehajtásához szükséges normaként e törvényjavaslatot. Más, részben jelzett tényezôk azonban (közöttük is elsôsorban, hogy a korábbi területfejlesztési rendszernek , vége”, új pedig nincs) okkal eredményezhették azt, hogy a Kormány a törvényjavaslat benyújtása mellett foglalt állást az elmúlt esztendốben. ${ }^{12}$

Ha végül készül terület- (és településfejlesztési?) törvény, annak mindenben meg kell felelnie a vele szemben támasztott követelményeknek, azaz olyan normának kell lennie, amely a területfej|esztés komplex, ágazatközi jellegére is tekintettel meg tudja jeleníteni, a jog nyelvére lefordítva, a területi politikát, a feladat- és eszközrendszereket, mindazon sajátosságokat, amelyek az ország település- és térszerkezeti jellemzôibôl stb. fakadnak. Az előkészítés idôszakában pedig fontos, hogy a különbözô szakmai és egyéb érdekszövetségek, önkormányzati szövetségek egyrészt mondhassanak véleményt, másrészt javaslataik vétessenek is figyelembe a törvényjavaslat véglegesítésekor.

Korántsem mindegy, miként alakul az , új területi politika”, s hogy ebben a folyamatban hol, miként és milyen erôvel lépnek/léphetnek be az önkormányzatok, a területi érdekközvetító mechanizmusok? A tisztázandó kérdések sokasága, úgy gondolom, még jelentôs feladatot ró a tơrvényelôkészítôkre. 
A területfejlesztési törvény nem kerülheti meg a középszint problémáját. Kérdés, hogy a mai „, lebegố” megyék élnek-e tovább, alapvetôen szolgáltató, intézményfenntartó kötelezettségükkel; kialakul-e egy kvázi ,,állami megye"; avagy erósödik a megye, új utakra lelve; avagy megszű̉nik önkormányzati egységként létezni, s helyét területi szinten más szervezetek, hivatalok, intézmények veszik át. Ettől függetlenül: a területi politika, illetổleg a területfejlesztési törvény fölveti a területbeosztás továbbgondolását az érdekvédelem képviselet tekintetében is.

\section{Jegyzetek}

'A tanulmány írása elốtt néhány hónappal a Kormány Békéscsabára , látogatott", s adott 500 milliót a megye hátrányos térségeire. Félreértés ne essék, nem az a baj, hogy ezek a területek pénzeszközket kaptak, hanem az, hogy hiányzik a normativitás, mindezeknek a komplex területi politikába történố beleágyazása. Így bármikor, bárki nyújthatja a kezét, hiszen nem túl nehéz szinte valamennyi térségról kimutatni annak hátrányos, halmozottan hátrányos, depressziós, válságos stb. voltát. Kérdés, hogy az itt jelzett esetekben milyen (intézményi) érdekrendszerek müködtek, kapcsolódtak be a döntések elốkészítésébe?

${ }^{2}$ No meg arra lenne szükség, hogy egyrészrôl kerüljük a joghézagokat, a ,, határozatlan” jogfogalmakat, s pontosan definiáljuk pl. a, ,vélemény nyilvánítás, -kikérés”, , ,állásfoglalás", , ,egyeztetés" tartalmát, jogi kötôerejét, a másik oldalról a ,figyelembevétel kötelezettségét", s végül a további eljárási kérdéseket.

${ }^{3}$ Esetleg úgy, hogy az eltéró érdekeket képviselố szervek érvei már elốzetesen , , kioltják" egy mást, s így meglehetôsen szabad kezet kaphatnak a döntéselôkészítôk a , vélemények figyelembevételével" kapcsolatos kötelezettségeik teljesítésekor, a döntések meghozatalakor.

${ }^{4}$ Maradva a Békés megyei példánál. Vajon mit szólnak ehhez a nem kevésbé hátrányos helyzetü baranyai, somogyi aprófalvak, határmenti térségek, vagy éppen a válságzónák önkormányzatai, polgárai? Pontosabban fogalmazva: van-e fórum arra, hogy szóljanak?

${ }^{5}$ Ahhoz képest is alakul, hogy az egyszintú önkormányzati rendszer mellett kiépült (kiépüló) két-, illetve három szintü közigazgatási rendszer (helyi-megyei-regionális) hol és hogyan kapcsolódik egymáshoz.

${ }^{6}$ Esetleg el lehetett volna, illetve el lehetne rendelni a területi politika alapkérdéseiról, a területfejlesztési törvényrổl (vagy kiemelt jelentôségũ, az ország egészére kiható ügyrôl, mint pl. Bôs-Nagymaros, a Világkiállítás vagy egy újabb atomerômư építése).

${ }^{7}$ Empírikus kutatásaink során a települési önkormányzatok túlnyomó része ilyen feladatokkal nem kívánta (volna) fölhatalmazni a megyét - félve, hogy újra túl nagy lesz a hatalma.

${ }^{8}$ Ilyen pl. a területfejlesztési szolgáltatások, a rendezési tervek karbantartása, módosítása, egyeztetések végrehajtása, döntéselôkészítés, kisebb tervezési munkák elvégzése, építészeti értékek felmérése, javaslatok mũemlékvédelmi kérdésekben, véleményezés és szaktanácsadás beruházási építési programokról, pályázati, fejlesztési elképzelésekrôl stb.

${ }^{9}$ Egy fontos megközelítési szempontra hadd hívjam fỏl a figyelmet: lehet, hogy más időszakban nem lenne ilyen tárgyú törvényre szülkség. De most egy , ,új rend" alapintézményeit kell kiépíteni az élet minden terén. Az viszont nem lehet kétséges, hogy a területi politika ilyennek minôsül (mármint, , alapvetô’' kérdéskörnek).

${ }^{10}$ Áttekintve a területfejlesztéshez kapcsolódó joganyagot, először is kitủnik, hogy nincsenek (itt sem) kaptafák. Az eltérố természeti, földrajzi, társadalmi, történelmi, gazdasági, népességi stb. viszonyok rövidebb-hoszszabb időszakonként is, egymáshoz képest más és más megoldásokat jelentenek - a fogalomhasználattól a szabályozások tárgyán, rendszerén keresztül az állami-önkormányzati szerepvállalásig, felelôsségig.

"Itt említem meg, bár az önkormányzati érdekképviseletekhez kapcsolódik, hogy egy kétkamarás parlament (a szakirodalomban az utóbbi idốkben errốl több publikáció is megjelent) lehetốvé tenné azt is, hogy a politikai érdekorientáció mellett megjelenjenek intézményes keretek között a területi érdekmechanizmusok. Ezt szolgálná pl. a területi gyưlés, amelybe helyet kapnának az önkormányzatok, azok szövetségei - különbözó, késôbb meghatározandó eljárások szerint.

12 Igaz, azóta mintha ,összekuszálódtak” volna a dolgok a már említett két ágazat közötti viták miatt. 


\section{FUNDAMENTAL ISSUES OF THE REPRESENTATION OF REGIONAL INTERESTS, OF REGIONAL POLICY AND NORMATIVE REGULATIONS}

\section{FERENC CSEFKÓ}

In the field of regional development, the author gives a short review of the mechanisms of interests which should be taken into consideration in order to make government decisions on concensual basis.

After exposing cetain fundamental issues of regional policy, the author makes an account of those corporate systems which can, in principle, play some role in the decision-making processes. Corporate systems at the level of local authorities and the association of settlements are given special emphasis.

The law on local authorities allows the local authorities to create different associations. However we have to note, that the settlements have not really used this opportunity during the last one-one and a half years. Instead, the counties were more initiative in many places and fields.

Associations covering the whole county, and established by the local authority of a county and the local authorities of the settlements have special role among the associations. Besides others, the aim of these associations is "...the more effective and rational solution of regional problems," "...management of enterprises and ventures, and organization of regional services." In its complexity, this type of association is almost equal to a medium-level of supply and service if it has planning and development tasks as well. Their activities are, at the same time, realized in concrete decisions on regional development. Consequently, the main and the decisive part of the tasks of the associations are found in settlement and regional development.

The associations of settlements and the different associations of small regions can join effectively in the formation of regional policy. They are free to practise their rights in legislation, but they can also participate in the elaboration of mechanisms helping the coordination of interests, and in the development of large investment projects, regional programs, etc. Another group of their tasks can be the organization of services, the development of information flow, solution of the conflicts of interests, putting up tenders, supporting the development of international-regional connections. These associations can also collaborate with each other in the elaboration of the tasks of the national economy influencing the region, in decreasing regional differences and the differences in chances and opportunities, extending this way the present means of regional development.

The author deals with the counties from the point of view of the corporate system. The law on regional development can, in no way, avoid the problems of the medium level. It cannot be decided as yet, whether the present ,floating" counties will survive with their obligation to care about the fundamental services and the maintenance of the institutions; or a , govermental county" will develop; or the counties will strengthen through finding new ways of their own; or the counties will cease to exist as local governmental units, and their roles 
will be fulfilled by other organizations, offices, institutions at a regional level. Independent from this, regional policy and the law on regional development raise the issue of regional disribution as well, also in respect of the corporate system.

The last part of the study lists the most important items of normative regulation. A lot of space is devoted to discuss the necessity of legal legislation, and if they are considered to be necessary, those key issues have to be identified, that can guarantee the birth of an executive and executable norm, which helps, through legal means, the development of a smaller or bigger region, and the improvement of the living conditions of people living there.

Translated by J. Mészáros

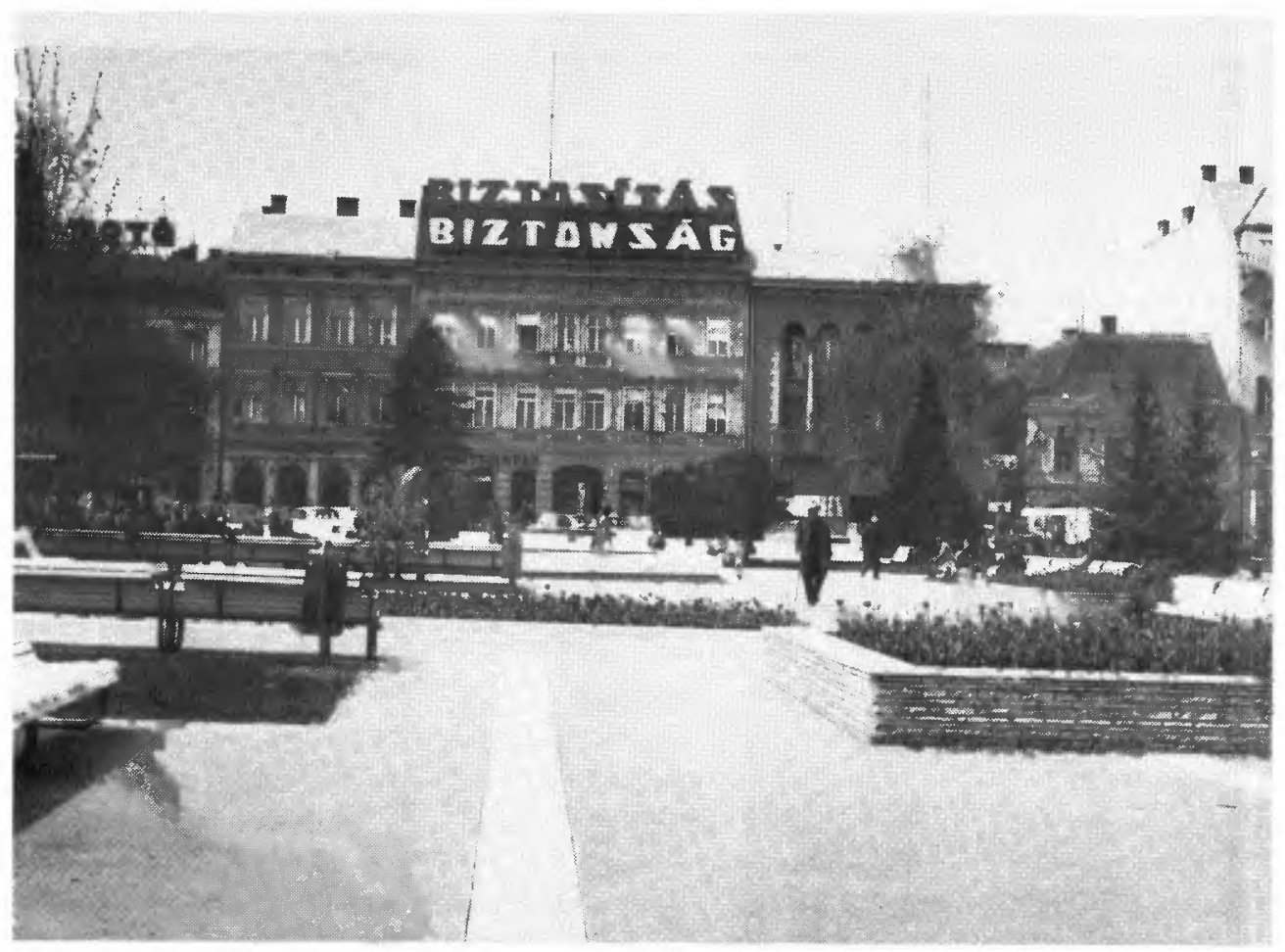

